\begin{tabular}{|c|c|c|}
\hline 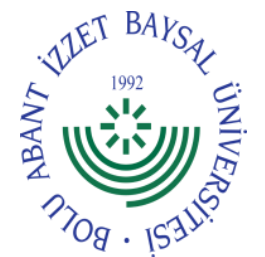 & $\begin{array}{l}\text { International Journal of Agriculture and Wildlife } \\
\qquad \text { Science } \\
\text { http://dergipark.org.tr/ijaws }\end{array}$ & 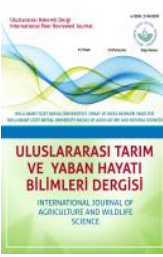 \\
\hline
\end{tabular}

Research Article

\title{
Comparative Analysis of Artificial Intelligence and Nonlinear Models for Broiler Growth Curve
}

\author{
Erdem Küçüktopcu* (D) Bilal Cemek \\ Department of Agricultural Structures and Irrigation, Faculty of Agriculture, Ondokuz Mayıs University, Samsun, Turkey
}

Received: 02.09.2021 Accepted: 20.10.2021

Keywords:
Growth curve, broiler,
artificial intelligence, regression model

*Corresponding author erdem_kt@hotmail.com

\begin{abstract}
Numerous mathematical expressions for growth models have been developed, but each has its own characteristics and limitations. Therefore, this study has investigated whether artificial intelligence (Al) methods can be an alternative to these models. To this aim, four nonlinear (NL) models (logistic, Richards, Gompertz-Laird, and von Bertalanffy) and three Al techniques - artificial neural networks (ANN), integrated adaptive neuro-fuzzy inference systems with grid partitioning and subtractive clustering (ANFIS-GP and ANFIS-SC) - were used to analyze growth. Some statistical methods, including the mean absolute error (MAE), root mean square error (RMSE) and mean absolute percentage error (MAPE) were used to evaluate the model performance. As a result of the study, it was determined that the ANFIS-SC model yielded a better fit with the broiler data due to its low MAE, RMSE, and MAPE values ( $7.68 \mathrm{~g}, 11.93 \mathrm{~g}$, and $1.06 \%$, respectively). The overall recommendation of this study is that the Al models could be used as an alternative to determine a broiler growth curve.
\end{abstract}

\section{Etlik Piliç Büyüme Eğrisinin Tahmininde Yapay Zeka ve Doğrusal Olmayan Modellerin Karşılaştırmalı Analizi}

Anahtar kelimeler:
Büyüme eğrisi, etlik piliç,
yapay zeka, regresyon
modeli

\begin{abstract}
Özet. Büyüme modelleri için çok sayıda matematiksel ifade geliştirilmiştir, ancak her birinin kendine has özellikleri ve sınırlamaları bulunmaktadır. Dolayısıyla bu çalışmada yapay zeka (YZ) yöntemlerinin bu modellere alternatif olup olamayacağı araştırımıştır. Bu amaçla büyümeyi analiz etmek için dört farklı doğrusal olmayan model (NL) (lojistik, Richards, Gompertz-Laird ve von Bertalanffy) ve üç farklı YZ tekniği - yapay sinir ağları (YSA) ve uyarlamalı sinirsel bulanık çıkarım sisteminin farklı yöntemleri ( Izgara bölümleme (ANFIS-GP) ve eksiltici kümeleme (ANFIS-SC)) kullanılmıştır. Modellerin performansını değerlendirmek için ortalama mutlak hata (MAE), ortalama karekök hata (RMSE) ve ortalama mutlak yüzde hata (MAPE) gibi bazı istatistiksel yöntemler ele alınmıştır. Çalışma sonucunda ANFIS-SC modelinin en düşük MAE, RMSE ve MAPE değerleri (sırasıyla 7.68 g, $11.93 \mathrm{~g}$ ve \%1.06) ile gerçek ağırlık verileriyle daha iyi uyum sağladığı tespit edilmiştir. Sonuç olarak YZ modellerinin etlik piliç büyüme eğrisini belirlemek için alternatif olarak kullanılabileceği belirlenmiştir.
\end{abstract}




\section{INTRODUCTION}

Broiler industry requires birds that can grow faster and produce a high-quality carcass in the shortest time. It is important for broiler businesses to have sufficient information about the growth of the chickens in terms of profitability and continuity (Chang, 2007; Abdurofi et al., 2017).

Growth curves, an economically important feature of the broiler industry, are used to describe the changes in weight and body size per unit of time or age. Modeling growth curves is advantageous because it enables visualization of growth patterns over time, and the resulting equations can be used to predict the expected weight of chickens at a given age (Eleroğlu et al., 2014; Koushandeh et al., 2019).

Some nonlinear (NL) models (e.g., logistic, Richards, Gompertz-Laird, and von Bertalanffy) have been used widely to describe poultry growth curves, and the comparison of NL models was generally recommended to determine the best model based on different assessment criteria for species, strains, and even different lines. Numerous researchers have used NL models to investigate and characterize the growth curves of various poultry species, including Cetin et al. (2007), Balcioğlu et al. (2009), and Sariyel et al. (2017) in partridge, Raji et al. (2014), and Narinc et al. (2014) in quail, Vitezica et al. (2010) and Tang et al. (2010) in duck, Şengül and Kiraz (2005) and Porter et al. (2010) in turkey, van der Klein et al. (2020) in laying hens, and Roush et al. (2006), Topal and Bolukbasi (2008), Ahmad (2009), Şekeroğlu et al. (2013), Demuner et al. (2017) and Koushandeh et al. (2019) in broiler. These $\mathrm{NL}$ models can describe the growth of chickens, but each one has unique characteristics and shortcomings (Norris et al., 2007).

Recently, artificial intelligence (Al) techniques offer an alternative to complicated NL models. A significant advantage of using Al compared to NL models is that Al modeling could only be performed on a dependent variable, and it is also possible to design various types of the variable in Al modeling. This results in less time and resource waste, a more accurate error estimation, and less variability in data collection under various conditions. Another important advantage of Al models is that they could effectively handle the nonlinearity and complexity of a system and overcome the limitations of NL models (Haykin, 2010; Shanmuganathan, 2016). In recent years, several studies have been performed to compare the performance of artificial neural networks (ANN) and NL models in broiler growth estimation (Roush et al., 2006; Ahmad, 2009; Koushandeh et al., 2019).

These studies have contributed significantly to the knowledge base regarding the ANN technique in poultry houses. However, to our knowledge, no comprehensive study has been conducted to compare different NL models, neuro-fuzzy, and neural networks techniques for broiler growth curve.

Therefore, the main objective of the present study is to compare the different Al techniques and NL growth models to identify which is most suitable for the data of the "Ross 308 " chickens.

\section{MATERIAL AND METHOD}

The research was conducted in Samsun, Turkey $\left(41^{\circ} 70^{\prime} \mathrm{N}, 36^{\circ} 30^{\prime} \mathrm{E}\right)$, at a commercial broiler farm. The farm had a length of $90.00 \mathrm{~m}$, a width of $14.00 \mathrm{~m}$, and a height of $3.80 \mathrm{~m}$ (Figure 1).

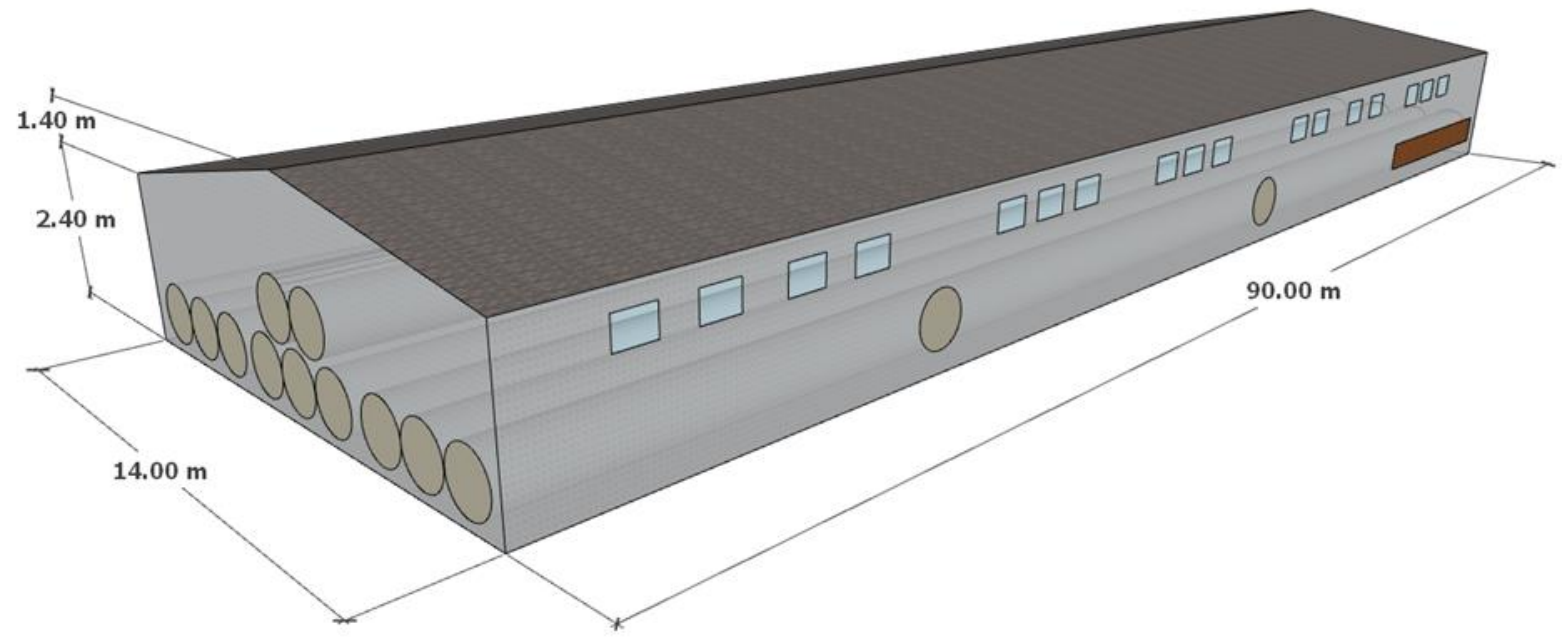

Figure 1.The dimensions of the broiler house.

Şekil 1. Kümesin boyutları. 
Chickens from the "Ross 308" breeding stock were reared until 40-42 days old. Ventilation, heating, lighting, feeding, and watering were all controlled by an automatic control system. Chicken weights were recorded daily at eight rearing seasons (Table 1) using an electronic poultry weighing scale. The average of eight rearing seasons was used as the body weight of chickens for the growth curve to be modeled.

Table 1. Broiler rearing seasons and dates.

Çizelge 1. Etlik piliç yetiştirme dönemleri ve tarihleri.

\begin{tabular}{lll}
\hline Seasons & Dates & Number of birds \\
\hline S1 & $03.02 .2018-16.03 .2018$ & 20,035 \\
S2 & $09.04 .2018-20.05 .2018$ & 19,840 \\
S3 & $12.06 .2018-22.07 .2018$ & 24,000 \\
S4 & $09.11 .2018-19.12 .2018$ & 19,440 \\
S5 & $09.01 .2019-18.02 .2019$ & 17,760 \\
S6 & $14.03 .2019-24.04 .2019$ & 18,000 \\
S7 & $16.07 .2019-26.08 .2019$ & 18,240 \\
S8 & $11.09 .2019-23.10 .2019$ & 18,384 \\
\hline
\end{tabular}

\section{Nonlinear (NL) Model}

Four growth models were selected to characterize the growth pattern of "Ross 308" chickens: Logistic (Eq. 1), Richards (Eq. 2), Gompertz-Laird (Eq. 3), and von Bertalanffy (Eq. 4). Mathematical equations were as follows:

$$
\begin{gathered}
\text { Logistic } \rightarrow W_{t}=W_{A} /\left[1+\exp -K\left(t-t_{i}\right)\right] \\
\text { Richards } \rightarrow W_{t}=W_{A}\left[1-(1-m) \exp \left[-K\left(t-t_{i}\right) / m^{m /(1-m)}\right]\right]^{1 /(1-m)} \\
\text { Gompertz-Laird } \rightarrow W_{t}=W_{0} \exp [(L / K)(1-\exp -K t)] \\
\text { Von Bertalanffy } \left.\rightarrow W_{t}=W_{A}\left[1-B \exp ^{(-K t)}\right)\right]^{3}
\end{gathered}
$$

where, $W_{t}$ is the bird weight at time $t(\mathrm{~g}), W_{0}$ is the initial (hatch) weight $(\mathrm{g}), K$ is the maximum relative growth $\left(\mathrm{g} \mathrm{D}^{-1}\right), L$ is the instantaneous growth rate $\left(\mathrm{g} \mathrm{D}^{-1}\right), t_{i}$ is the age at the maximum rate of growth $(D)$, and $m$ is a shape parameter and $B$ is the integration constant. The asymptotic weight $\left(W_{A}\right)(\mathrm{g})$ and age of maximum growth $\left(t_{i}\right)(D)$ were estimated using the following formulas:

$$
\begin{gathered}
t_{i}=(1 / K) \log (L / K) \\
W_{A}=W_{0} \exp (L / K)
\end{gathered}
$$

\section{Artificial Neural Networks (ANN)}

This paper employed multi-layered feedforward back-propagation (MLP) during network training due to its speed and power. The tangent sigmoid (tansig) and linear transfer functions (purelin) were used in the hidden and output layers, respectively. The MLP can have multiple hidden layers; however, studies have shown that a single layer is sufficient for any neural network to approximate complex nonlinear functions. Therefore, one hidden layer was tested, and the number of neurons changed from 7 to 15 to achieve the optimal training network.

\section{Adaptive Neuro-Fuzzy Inference System (ANFIS)}

This system combines the fuzzy inference system's decision-making process (FIS) with the learning capability of ANN. As is the case with ANN, ANFIS learns with samples from a training set. This method yields the optimal network structure for resolving the problem at hand. The test procedure is carried out on previously unobserved samples, which enables the identification of the effect. The smaller error values attest to the conformity of the ANFIS model. One of ANN's primary drawbacks is its inability to justify the weight values acquired. This problem is addressed by the FIS, which is incorporated into the ANFIS structure. Different identifications such as subtractive clustering (SC) and grid partitioning (GP) can be applied in the ANFIS model. It is necessary to define the 
appropriate cluster radius in ANFIS-SC to apply fuzzy rules. The cluster radius denotes a cluster's sphere of influence, assuming that the data space is a unit hypercube, with a range of zero to one. The smaller the cluster radius, the more rules are generated, while the larger the cluster radius, the fewer rules are generated. Suitable values for radii usually fall between 0.2 and 0.5 . To determine the best estimation model, the cluster radius in this study ranged between 0.1 and 1. In ANFIS-GP models, three methods, including Gaussian, triangular, trapezoidal, and three membership functions (MFs) $(3,4$, and 5), were considered in the data processing.

\section{Model Performance Evaluation Criteria}

The mean absolute error (MAE), root mean square error (RMSE) and mean absolute percentage error (MAPE) were used to evaluate model performance. The equations are expressed as follows (Waller, 2003):

$$
\begin{array}{r}
M A E=\frac{\sum_{i=1}^{n}\left(\left|X_{\text {mea }, i}-X_{\text {est }, i}\right|\right)}{n} \\
R M S E=\sqrt{\frac{\sum_{i=1}^{n}\left(X_{\text {mea }, i}-X_{\text {est }, i}\right)^{2}}{n}} \\
M A P E=\frac{\sum_{i=1}^{n}\left(\mid \frac{X_{\text {mea }, i}-X_{\text {est }, i} \mid}{\left.X_{\text {mea }, i} \mid\right)}\right.}{n} \times 100
\end{array}
$$

where $X_{\text {mea, }}$ is the measured value of variable, $X_{\text {est }, i}$ is the estimated value of variable, and $n$ is the data number.

\section{RESULTS AND DISCUSSION}

The studied training and testing data for the estimation of chicken weight are presented in Table 2. Starting from day 0 , the even numbers of data were used as training, while the odd numbers of data were used as testing.

Table 2. Broiler weight data used for modeling in training and testing.

Çizelge 2. Eğitim ve test için modellemede kullanılan piliç ağırlık verileri.

\begin{tabular}{llll}
\hline Training & & Testing & Weight (g) \\
\hline Age (D) & Weight (g) & Age (D) & 55 \\
0 & 46 & 1 & 85 \\
2 & 70 & 3 & 125 \\
4 & 103 & 5 & 170 \\
6 & 146 & 7 & 236 \\
8 & 201 & 9 & 315 \\
10 & 275 & 11 & 423 \\
12 & 364 & 13 & 536 \\
14 & 482 & 15 & 673 \\
16 & 599 & 17 & 797 \\
18 & 740 & 19 & 978 \\
20 & 876 & 21 & 1118 \\
22 & 1044 & 23 & 1294 \\
24 & 1204 & 25 & 1388 \\
26 & 1361 & 27 & 1585 \\
28 & 1505 & 29 & 1762 \\
30 & 1662 & 31 & 1959 \\
32 & 1881 & 33 & 2118 \\
34 & 2008 & 35 & 2260 \\
36 & 2187 & 37 & 2408 \\
38 & 2353 & 39 & 2485 \\
40 & 2449 & 41 & \\
\hline
\end{tabular}


Four NL models, including logistic, Richards, Gompertz-Laird, and Von Bertalanffy, and three Al models, namely ANN, ANFIS-GP, and ANFIS-SC, were used to explore the "Ross 308" chickens growth patterns. The developed equations for four NL models for growth are presented in Table 3.

Table 3. Developed NL model equations for growth.

Çizelge 3. Büyüme modelleri için geliștirilmiş NL eşitlikleri.

\begin{tabular}{ll}
\hline Model & Equation \\
\hline Logistic & $W_{t}=2878.01 /[1+\exp -0.13(t-26.90)]$ \\
Richards & $W_{t}=4057.52\left[1+0.03 \exp \left[-0.02(t-27.83) / 1.03^{-34.33}\right]\right]^{-33.34}$ \\
Gompertz-Laird & $W_{t}=4143.98 \exp [-\log (4143.98 / 0.09) \exp (-0.05 t)]$ \\
von Bertalanffy & $W_{t}=6217.74\left[1-0.87 \exp ^{(-0.03 t)}\right]^{3}$ \\
\hline
\end{tabular}

A developed ANN model can be represented as:

$$
\text { BroilerWeight }=\sum_{k=1}^{m}\left(\left[\frac{2}{1+\exp \left(-2\left(\sum_{j=1}^{m} \sum_{i=1}^{n}\left(\left(w_{1}(i, j) x(i)\right)+b_{1}(j)\right)\right)\right)}-1\right]\right) w_{2}(k) b_{2}
$$

$w_{1}, w_{2}$ and $b_{1}, b_{2}$, are the weight and bias values of the network, respectively, $x$ symbolizes the input data, $m$ and $n$ are the number of neurons in hidden and input layers, respectively. The $w_{1}, w_{2}, b_{1}$, and $b_{2}$ values of the developed model are given in Table 4.

Table 4. Weight and bias values of the network.

Çizelge 4. Ağın ağırlık ve bias değerleri.

$\begin{array}{r}\text { Weights } \\ \hline w_{1}=\left[\begin{array}{r}32.002 \\ 26.414 \\ 0.077 \\ 3.110 \\ -1.201 \\ 0.139 \\ -7.459 \\ -11.897 \\ -29.796 \\ -17.098\end{array}\right] \quad w_{2}=\left[\begin{array}{r}640.544 \\ 75.914 \\ 946.895 \\ 48.784 \\ 117.264 \\ 425.393 \\ -100.590 \\ 2.324 \\ 1.457 \\ 1.164\end{array}\right] \quad b_{1}=\left[\begin{array}{r}32.657 \\ 42.047 \\ -1.565 \\ 10.923 \\ -19.147 \\ -4.834 \\ -29.137 \\ 51.763 \\ 4.719 \\ 43.657\end{array}\right] \\ \hline\end{array}$

ANFIS-GP model with Gauss method (3 MF) was selected as the best model, whereas ANFIS-SC with the cluster radius of 0.234 yielded the best results for estimating $\mathrm{BW}$.

In the training period, it is obvious from Table 5 that the MAE values were 31.41, 20.67, 10.53, 16.78, 6.70,4.53, and $5.39 \mathrm{~g}$ for logistic, Richards, Gompertz-Laird, von Bertalanffy, ANN, ANFIS-GP, and ANFIS-SC, respectively. The results indicate that the ANFIS-GP model had the lowest MAE $(4.53 \mathrm{~g})$, whereas the logistic model had the highest value $(31.41 \mathrm{~g})$. Similarly, the RMSE value for ANFIS-GP was $6.36 \mathrm{~g}$, while it was $35.05 \mathrm{~g}$ for logistic. Additionally, MAPE values for Al models ranged between 0.59 and $0.81 \%$, whereas they varied between 2.22 and $12.34 \%$ for NL models.

In the testing period, the MAE values varied between $14.47-32.23 \mathrm{~g}$ and $7.68-8.99 \mathrm{~g}$ for NL and Al models, respectively. As with the MAE criterion, the ANFIS-SC model had the lowest RMSE value (11.93 g), while the logistic model produced the highest RMSE value $(36.28 \mathrm{~g})$. Similarly, MAPE values varied between 1.06 and $10.64 \%$, depending on the model under consideration (Table 6). 
Table 5. Error values of NL models and Al techniques used to predict weights for training dataset. Çizelge 5. Eğitim veri seti için ağırlık tahmininde kullanılan NL ve YZ tekniklerinin hata değerleri.

\begin{tabular}{|c|c|c|c|c|c|c|c|}
\hline Weight (g) & Logistic & Richards & $\begin{array}{l}\text { Gompertz- } \\
\text { Laird }\end{array}$ & $\begin{array}{l}\text { von } \\
\text { Bertalanffy }\end{array}$ & ANN & ANFIS-GP & ANFIS-SC \\
\hline 46 & 84.61 & 52.46 & 39.42 & 14.92 & 46.00 & 45.34 & 45.89 \\
\hline 70 & 108.78 & 80.54 & 63.99 & 38.77 & 70.00 & 71.88 & 70.49 \\
\hline 103 & 139.51 & 118.79 & 98.76 & 76.96 & 103.00 & 100.44 & 102.04 \\
\hline 146 & 178.37 & 168.89 & 145.69 & 130.51 & 144.21 & 147.29 & 146.71 \\
\hline 201 & 227.16 & 232.19 & 206.40 & 199.56 & 202.86 & 202.78 & 201.94 \\
\hline 275 & 287.86 & 309.58 & 282.01 & 283.65 & 276.51 & 270.95 & 272.10 \\
\hline 364 & 362.57 & 401.40 & 373.00 & 381.88 & 366.86 & 368.47 & 368.69 \\
\hline 482 & 453.27 & 507.39 & 479.20 & 493.04 & 474.68 & 478.98 & 477.23 \\
\hline 599 & 561.59 & 626.74 & 599.80 & 615.77 & 599.21 & 600.26 & 600.71 \\
\hline 740 & 688.46 & 758.12 & 733.41 & 748.61 & 737.99 & 738.69 & 739.92 \\
\hline 876 & 833.67 & 899.83 & 878.22 & 890.05 & 887.03 & 880.14 & 879.11 \\
\hline 1044 & 995.58 & 1049.86 & 1032.09 & 1038.64 & 1041.70 & 1036.42 & 1036.05 \\
\hline 1204 & 1170.92 & 1206.07 & 1192.70 & 1192.96 & 1198.15 & 1212.19 & 1212.52 \\
\hline 1361 & 1354.92 & 1366.26 & 1357.73 & 1351.65 & 1354.85 & 1359.24 & 1359.51 \\
\hline 1505 & 1541.72 & 1528.29 & 1524.89 & 1513.47 & 1513.33 & 1495.58 & 1495.95 \\
\hline 1662 & 1725.10 & 1690.18 & 1692.06 & 1677.28 & 1677.33 & 1677.84 & 1680.17 \\
\hline 1881 & 1899.30 & 1850.14 & 1857.35 & 1842.04 & 1849.29 & 1865.90 & 1859.84 \\
\hline 2008 & 2059.66 & 2006.61 & 2019.10 & 2006.80 & 2025.42 & 2016.37 & 2020.27 \\
\hline 2187 & 2203.08 & 2158.30 & 2175.96 & 2170.75 & 2193.81 & 2185.17 & 2189.69 \\
\hline 2353 & 2328.08 & 2304.16 & 2326.81 & 2333.15 & 2339.73 & 2352.78 & 2344.87 \\
\hline 2449 & 2434.58 & 2443.39 & 2470.83 & 2493.37 & 2454.02 & 2449.29 & 2452.29 \\
\hline MAE & 31.41 & 20.67 & 10.53 & 16.78 & 6.70 & 4.53 & 5.39 \\
\hline RMSE & 35.05 & 24.30 & 13.56 & 20.26 & 10.08 & 6.36 & 7.87 \\
\hline MAPE & 12.34 & 5.87 & 2.22 & 8.28 & 0.61 & 0.81 & 0.59 \\
\hline
\end{tabular}

Table 6. Error values of NL models and Al techniques used to predict weights for testing dataset. Çizelge 6. Test veri seti için ağırlık tahmininde kullanılan NL ve YZ tekniklerinin hata değerleri.

\begin{tabular}{|c|c|c|c|c|c|c|c|}
\hline Weight (g) & Logistic & Richards & $\begin{array}{l}\text { Gompertz- } \\
\text { Laird }\end{array}$ & $\begin{array}{l}\text { von } \\
\text { Bertalanffy }\end{array}$ & ANN & ANFIS-GP & ANFIS-SC \\
\hline 55 & 95.96 & 65.34 & 50.56 & 25.15 & 55.61 & 59.43 & 57.99 \\
\hline 85 & 123.23 & 98.28 & 79.97 & 55.98 & 84.16 & 84.42 & 84.76 \\
\hline 125 & 157.82 & 142.27 & 120.59 & 101.79 & 119.82 & 121.84 & 122.81 \\
\hline 170 & 201.40 & 198.83 & 174.24 & 163.11 & 171.79 & 174.53 & 173.13 \\
\hline 236 & 255.89 & 269.09 & 242.30 & 239.78 & 237.69 & 233.71 & 234.15 \\
\hline 315 & 323.33 & 353.69 & 325.58 & 331.07 & 319.52 & 316.61 & 317.57 \\
\hline 423 & 405.80 & 452.66 & 424.24 & 435.92 & 418.59 & 423.04 & 422.00 \\
\hline 536 & 505.15 & 565.46 & 537.78 & 553.05 & 534.97 & 537.36 & 536.36 \\
\hline 673 & 622.69 & 691.02 & 665.09 & 681.02 & 667.04 & 668.20 & 669.49 \\
\hline 797 & 758.83 & 827.81 & 804.55 & 818.35 & 811.52 & 809.17 & 809.46 \\
\hline 978 & 912.70 & 973.94 & 954.16 & 963.55 & 963.94 & 954.76 & 953.46 \\
\hline 1118 & 1081.84 & 1127.33 & 1111.70 & 1115.17 & 1119.87 & 1124.67 & 1124.84 \\
\hline 1294 & 1262.19 & 1285.80 & 1274.81 & 1271.83 & 1276.45 & 1290.58 & 1291.41 \\
\hline 1388 & 1448.36 & 1447.17 & 1441.18 & 1432.24 & 1433.66 & 1424.62 & 1423.67 \\
\hline 1585 & 1634.22 & 1609.37 & 1608.60 & 1595.20 & 1594.40 & 1579.91 & 1583.33 \\
\hline 1762 & 1813.67 & 1770.50 & 1775.05 & 1759.61 & 1762.36 & 1777.40 & 1774.36 \\
\hline 1959 & 1981.44 & 1928.90 & 1938.76 & 1924.48 & 1937.41 & 1942.81 & 1939.76 \\
\hline 2118 & 2133.61 & 2083.12 & 2098.22 & 2088.93 & 2111.54 & 2095.85 & 2104.23 \\
\hline 2260 & 2267.91 & 2232.01 & 2252.19 & 2252.18 & 2270.36 & 2276.08 & 2271.66 \\
\hline 2408 & 2383.60 & 2374.64 & 2399.72 & 2413.57 & 2401.04 & 2408.75 & 2405.61 \\
\hline 2485 & 2481.19 & 2510.34 & 2540.08 & 2572.48 & 2498.94 & 2481.70 & 2485.16 \\
\hline MAE & 32.23 & 24.51 & 14.47 & 20.42 & 8.99 & 8.76 & 7.68 \\
\hline RMSE & 36.28 & 27.62 & 20.53 & 27.71 & 13.56 & 12.83 & 11.93 \\
\hline MAPE & 10.64 & 5.98 & 2.11 & 6.78 & 1.99 & 1.32 & 1.06 \\
\hline
\end{tabular}


After comparing the results of NL and Al models, model estimation ability (ANFIS-SC $>$ ANFIS-GP $>$ ANN $>$ Gompertz-Laird > Richards > von Bertalanffy > logistic) was determined for chicken weight estimation. At an early age, von Bertalanffy and Gompertz-Laird models underestimated weights, whereas the logistic model overestimated weights. Richards model was consistently overestimated weights at all ages. Yakupoglu and Atil (2001) compared the Gompertz and von Bertalanffy models to weekly body weight values in broiler flocks, and they reported that Gompertz was better than von Bertalanffy. Adenaike et al. (2017) found that Gompertz and von Bertalanffy models performed equally well at predicting chicken growth curves. Mouffok et al. (2019) stated that the Gompertz model was the most suitable for estimating broiler weight before four weeks of age, and after one month of age, the von Bertalanffy model was the best predictor of light chicken weights.

The growth pattern for "Ross 308" chicken by actual broiler weight and ANFIS-SC model are presented in Figure 2. Comparing the estimations with other Al studies, the RMSE and MAPE values of developed model were found lower than the studies of Berberoğlu and Özkan (2020), Koushandeh et al. (2019), and Roush et al. (2006).

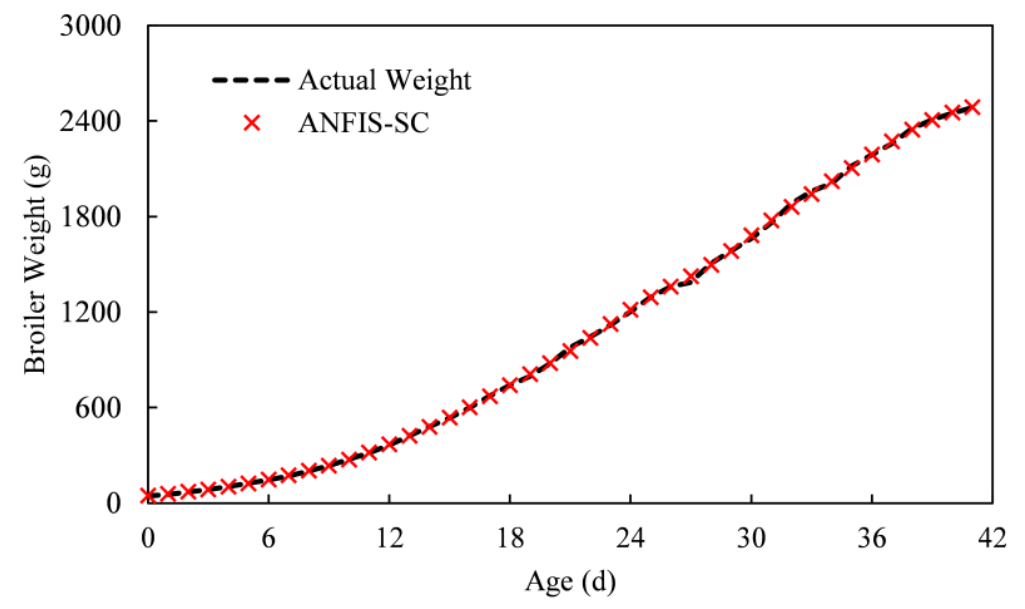

Figure 2. The weight of broilers used as testing data for the ANFIS-SC. Şekil 2. ANFIS-SC modeli için test verisi olarak kullanılan etlik piliç ağırlığı.

Applying an Al model to make predictions for poultry growth, several advantages can be achieved, such as faster predictions using less time and resources. Al models are more accessible, require fewer variables, and perform more efficiently when determining poultry growth, but only if the data is appropriately handled.

\section{CONCLUSION}

In this research, the growth model of "Ross 308" chicken was compared using NL models and Al techniques. Based on the comparison of these results, Al techniques were superior to NL models for modeling broiler growth. Of all Al techniques studied in this research, the ANFIS-SC model best describes the growth pattern of "Ross 308" chicken based on MAE, RMSE, and MAPE $(7.68 \mathrm{~g}, 11.93 \mathrm{~g}$ and 1.06\%, respectively) for the testing data. In summary, this study demonstrates that Al techniques could be used effectively to identify broiler growth curves and is thus recommended as an alternative approach.

\section{CONFLICT OF INTEREST}

The authors declare that they have no conflict of interest.

\section{DECLARATION OF AUTHOR CONTRIBUTION}

E.K. designed and performed the experiments, derived the models, and analyzed the data, B.C. was involved in planning and supervised the work. E.K. and B.C. wrote the manuscript.

\section{ACKNOWLEDGMENT}

This research was funded by the Ondokuz Mayıs University Scientific Research Projects Department (PYO.ZRT.1901.18.018). 


\section{REFERENCES}

Abdurofi, I., Ismail, M. M., Kamal, H., \& Gabdo, B. (2017). Economic analysis of broiler production in Peninsular Malaysia. International Food Research Journal, 24(2), 761-766.

Adenaike, A. S., Akpan, U., Udoh, J. E., Wheto, M., Durosaro, S. O., Sanda, A. J., \& Ikeobi, C. O. N. (2017). Comparative evaluation of growth functions in three broiler strains of nigerian chickens. Pertanika Journal of Tropical Agricultural Science, 40(4), 611-620.

Ahmad, H. (2009). Poultry growth modeling using neural networks and simulated data. Journal of Applied Poultry Research, 18(3), 440-446

Balcioğlu, M. S., Kizilkaya, K., Karabağ, K., Alkan, S., Yolcu, H. İ., \& Şahin, E. (2009). Comparison of growth characteristics of chukar partridges (Alectoris chukar) raised in captivity. Journal of Applied Animal Research, 35(1), 21-24.

Berberoğlu, E., \& Özkan, N. (2020). Estimation and comparison of growth curve in broilers through the artificial neural networks and gompertz models. Journal of Agricultural Faculty of Gaziosmanpasa University, 37(2), 68-76.

Cetin, M., Sengul, T., Sogut, B., \& Yurtseven, S. (2007). Comparison of growth models of male and female partridges. Journal of Biological Sciences, 7(6), 964-968.

Chang, H.S. (2007). Overview of the world broiler industry: Implications for the Philippines. Asian Journal of Agriculture and Development, 4, 67-82.

Demuner, L. F., Suckeveris, D., Muñoz, J. A., Caetano, V. C., Lima, C. G. D., Faria, D. E. D., \& Faria, D. E. D. (2017). Adjustment of growth models in broiler chickens. Pesquisa Agropecuária Brasileira, 52, 1241-1252.

Eleroğlu, H., Yıldırım, A., Şekeroğlu, A., Çoksöyler, F. N., \& Duman, M. (2014). Comparison of growth curves by growth models in slow-growing chicken genotypes raised the organic system. International Journal of Agriculture and Biology, 16(3), 529535.

Haykin, S. (2010). Neural Networks and Learning Machines. Pearson Education, New Jersey.

Koushandeh, A., Chamani, M., Yaghobfar, A., Sadeghi, A., \& Baneh, H. (2019). Comparison of the accuracy of nonlinear models and artificial neural network in the performance prediction of Ross 308 broiler chickens. Poultry Science Journal, 7(2), 151161.

Narinc, D., Karaman, E., Aksoy, T., \& Firat, M. Z. (2014). Genetic parameter estimates of growth curve and reproduction traits in Japanese quail. Poultry Science, 93(1), 24-30.

Norris, D., Ngambi, J. W., Benyi, K., Makgahlele, M. L., Shimelis, H. A., \& Nesamvuni, E. A. (2007). Analysis of growth curves of indigenous male Venda and Naked Neck chickens. South African Journal of Animal Science, 37(1), 21-26.

Mouffok, C., Semara, L., Ghoualmi, N., \& Belkasmi, F. (2019). Comparison of some nonlinear functions for describing broiler growth curves of Cobb500 strain. Poultry Science Journal, 7(1), 51-61.

Porter, T., Kebreab, E., Kuhi, H. D., Lopez, S., Strathe, A. B., \& France, J. (2010). Flexible alternatives to the Gompertz equation for describing growth with age in turkey hens. Poultry Science, 89(2), 371-378.

Raji, A., Alade, N., \& Duwa, H. (2014). Estimation of model parameters of the Japanese quail growth curve using Gompertz model. Archivos de zootecnia, 63(243), 429-435.

Roush, W., Dozier, W., \& Branton, S. (2006). Comparison of Gompertz and neural network models of broiler growth. Poultry Science, 85(4), 794-797.

Sariyel, V., Aygun, A., \& Keskin, I. (2017). Comparison of growth curve models in partridge. Poultry Science, 96(6), 1635-1640.

Shanmuganathan, S. (2016). Artificial neural network modelling: An introduction. In S. Shanmuganathan, \& S. Samarasinghe (Eds.), Artificial Neural Network Modelling. Studies in Computational Intelligence (pp. 1-14). Cham, Germany: Springer.

Şekeroğlu, A., Tahtalı, Y., Sarıca, M., Gülay, M. Ş., Abacı, H. S., \& Duman, M. (2013). Comparison of growth curves of broiler under different stocking densities by gompertz model. Kafkas Universitesi Veteriner Fakültesi Dergisi, 19(4), 669-672.

Şengül, T., \& Kiraz, S. (2005). Non-linear models for growth curves in large white turkeys. Turkish Journal of Veterinary and Animal Sciences, 29(2), 331-337.

Tang, X., Li, J., Zhao, P., Liu, Z., \& Chen, Q. (2010). Study on growth and development and fitting of growth curve of Huainan partridge duck. Journal of Henan Agricultural Sciences, 2, 105-107.

Topal, M., \& Bolukbasi, Ş. (2008). Comparison of nonlinear growth curve models in broiler chickens. Journal of Applied Animal Research, 34(2), 149-152. 
van der Klein, S., Kwakkel, R., Ducro, B., \& Zuidhof, M. (2020). Multiphasic nonlinear mixed growth models for laying hens. Poultry Science, 99(11), 5615-5624.

Vitezica, Z., Marie-Etancelin, C., Bernadet, M.-D., Fernandez, X., \& Robert-Granie, C. (2010). Comparison of nonlinear and spline regression models for describing mule duck growth curves. Poultry Science, 89(8), 1778-1784.

Waller, D. L. (2003). Operations management: A supply chain approach. Cengage Learning Business Press, Boston.

Yakupoglu, C., \& Atil, H. (2001). Comparison of growth curve models on broilers growth curve l: Parameters estimation. Online Journal of Biological Sciences, 1(7), 680-681. 